\section{BAFF (B cell activating factor) transcript level in peripheral blood of patients with SLE is associated with same-day disease activity as well as global activity over the next year}

Eric Zollars, ${ }^{1}$ Jadwiga Bienkowska, ${ }^{2}$ Julie Czerkowicz, ${ }^{2}$ Norm Allaire, ${ }^{2}$ Ann M Ranger, ${ }^{2}$ Laurence Magder, ${ }^{3}$ Michelle Petri ${ }^{1}$

To cite: Zollars E, Bienkowska J, Czerkowicz J, et al. BAFF (B cell activating factor) transcript level in peripheral blood of patients with SLE is associated with same-day disease activity as well as global activity over the next year. Lupus Science \& Medicine 2015;2:e000063. doi:10.1136/lupus-2014000063

- Additional material is available. To view please visit the journal (http://dx.doi.org/ 10.1136/lupus-2014000063).

Received 25 September 2014 Revised 9 January 2015 Accepted 8 February 2015

CrossMark

\footnotetext{
${ }^{1}$ Division of Rheumatology, Johns Hopkins University School of Medicine, Baltimore, Maryland, USA ${ }^{2}$ Biogen Idec, Cambridge, Massachusetts, USA ${ }^{3}$ Epidemiology and Public Health, University of Maryland, Baltimore, Maryland, USA
}

Correspondence to Dr Michelle Petri; mpetri@jhmi.edu

\section{ABSTRACT}

Objectives: Quantitating gene expression is a potential method of developing biomarkers in systemic lupus erythematosus (SLE). Because of the known pathological role of $B$ cell activating factor (BAFF) in SLE, we explored the association between BAFF gene expression and clinical activity in SLE.

Methods: A total of 275 patients with SLE completed this phase of a prospective observational study. At entry into the study, the BAFF gene expression levels were determined in peripheral blood RNA. Serum concentration of BAFF protein was also measured. We then determined clinical associations with SLE disease history, SLE activity on the same day and SLE activity over the course of the next year.

Results: Elevated BAFF gene expression was associated with a history of more leucopenia and serologically with more autoantibodies (anti-dsDNA, anti-Sm, anti-Ro, anti-La and anti-RNP) and low complement. Patients with higher amounts of BAFF transcript had higher measured levels of clinical disease activity. Initial high levels of BAFF gene expression also predicted increased disease activity over the course of the next year. In contrast, serum concentration of BAFF protein was not strongly associated with same-day global disease activity or with future disease activity.

Conclusions: BAFF gene expression level is associated with clinical and serological SLE activity on the same day and predictive of clinical activity over the next year. BAFF gene expression is a better measure and predictor of SLE disease activity than the serum BAFF protein level.

\section{INTRODUCTION}

Systemic lupus erythematosus (SLE) is a heterogeneous disease with dysfunction in both the innate and adaptive components of the immune system, ${ }^{1}$ leading to inflammation in multiple organ systems. Periods of disease inactivity can be interrupted by flares of increased activity, or a patient may have chronic activity. ${ }^{2}$ No single clinical laboratory test is currently useful as an indicator of clinical disease activity. Attempts to establish markers have led to studies exploring titres of antibodies to double-stranded DNA (antidsDNA), ${ }^{3}$ levels of complement, ${ }^{4}$ erythrocyte sedimentation rate, ${ }^{5}$ chemokines ${ }^{6}$ and complement deposition on red blood cells. ${ }^{7}$

One approach to identify markers of disease activity is to investigate expression levels of genes thought to be involved in the pathogenesis or maintenance of SLE. The variable expression of cytokines determined by these genes is thought to contribute to SLE itself, as well as to the heterogeneity of SLE. ${ }^{8}$ The difficulty with cytokines is both their pleiotropic effects as well as the complex interactions among cytokines ${ }^{9}$ in some cases, leading to both proinflammatory and anti-inflammatory effects. Further, cytokines thought to be involved in the pathogenesis of SLE, such as interferon alpha, may not vary in states of high or low disease activity. ${ }^{10-12}$

$\mathrm{TNF} \alpha$ has been explored with conflicting results in SLE. ${ }^{13}$ However, a member of the TNF ligand family, B cell activating factor (BAFF), also known as B lymphocyte stimulator (BLyS), is thought to be closely tied to the pathogenesis of SLE (summarised in ref. ${ }^{14}$ ). BAFF is expressed by multiple cell types, including monocytes, activated neutrophils, T cells and dendritic cells. ${ }^{15-17}$ A variety of cytokines including interferon alpha, interferon gamma and TNF can induce its expression and secretion. Binding of BAFF to its receptors (of which there are three) leads to B cell proliferation, differentiation and survival, and IgG class switching. ${ }^{16} 1819$ Significant effects 
have been found on $\mathrm{T}$ cells as well, with binding leading to proliferation, cytokine production and skewing towards a Th1 cell profile. ${ }^{20-22}$ In mice, overexpression of BAFF leads to SLE-like features. ${ }^{19} 2324$ Elevated serum levels of BAFF were found in patients with SLE $^{25} 26$ though an early study did not suggest a correlation with disease activity. ${ }^{27}$ Since that time, a 2-year four-centre longitudinal study, ${ }^{28}$ a Norwegian study ${ }^{29}$ and a paediatric study $^{30}$ have shown correlation between serum BAFF protein levels and disease activity. A targeted therapy directed against BAFF, belimumab, is the first new therapy for SLE in 50 years. ${ }^{31}$ Treatment of lupus-prone $\mathrm{NZB} / \mathrm{W}$ mice with BAFF inhibition delayed renal disease and death. ${ }^{32}{ }^{33}$ Human trials found that inhibition of BAFF activity led to reduction in SLE activity as measured by the SLE Responder Index. ${ }^{31} 34$

The level of BAFF transcript expression may correlate better with disease activity than the serum level of the protein product. ${ }^{35}$ It was noted that, while BAFF was important in the pathogenesis of SLE, the association between serum BAFF protein levels and disease activity was weak. Collins and colleagues investigated BAFF mRNA levels from peripheral blood leucocytes and BAFF serum protein levels and compared both with SLE disease activity in 60 predominantly Hispanic (82\%) patients with SLE; 37 of whom had repeat levels drawn. They found that the mRNA levels were better correlated with disease activity measured by the SLE Disease Activity Index (both full-length mRNA and an alternatively spliced isoform). Interestingly, their subsequent work ${ }^{36}$ found that the BAFF protein level, but not the BAFF mRNA level, was increased in rheumatoid arthritis and declined in response to TNF antagonist therapy in good responders. However, mRNA levels were unchanged in either good or poor responders. This might reflect local versus systemic production and be due to differences between rheumatoid arthritis and SLE pathology.

In this study, we explored the association between BAFF gene expression, BAFF protein level and the associations with same-day and longitudinal clinical disease activity in SLE.

\section{PATIENTS AND METHODS}

Study population and design

The study protocol for SPARE (Study of biological Pathways, disease Activity and Response markers in patients with systemic lupus Erythematosus) was approved by the Johns Hopkins University School of Medicine Institutional Review Board. Patients with SLE were enrolled from the Hopkins Lupus Cohort following informed consent. Adult patients were eligible if they were aged 18-75 years old and met the definition of SLE as defined by the revised American College of Rheumatology classification criteria. ${ }^{37} 38$ At entry into the study (baseline), the patient's medical history was reviewed, and information on current medications was recorded. Visits were scheduled quarterly or more often if required for disease activity over a 2-year period. All patients were evaluated by the same physician at entry and all subsequent cohort visits (MP). A total of 306 patients with SLE were enrolled in the observational study. For 275 of the patients, levels of BAFF RNA were measured at baseline, and the clinical experience of patients in the next year was recorded at their quarterly clinic visits in the following year. The demographics were $58.9 \%$ Caucasian, $33.9 \%$ African-American, 91.1\% female, mean age $46.0 \pm 11.9$ years. The number of visits per patient over the following year ranged from 1 to 9 . Six patients had 1 visit, 46 patients had 2-3 visits, 159 patients had 4 visits, and 81 patients had more than 4 visits.

Patients were treated according to standard clinical practice. To assess disease activity, the Safety of Estrogens in Lupus Erythematosus: National Assessment (SELENA) version of the Systemic Lupus Erythematosus Disease Activity Index (SLEDAI) $)^{39}{ }^{40}$ as well as the physician global assessment $(\mathrm{PGA})^{41}$ were completed at each visit. C3, C4, anti-dsDNA (Crithidia), complete blood cell count and urinalysis were performed at every visit.

\section{Sample preparation}

Peripheral blood samples used for gene expression analyses were collected using the PAXgene Blood RNA system (PreAnalytiX GmbH). RNA was isolated from PAXgene preserved blood using the Agencourt RNAdvance Blood kit automated on an Arrayplex liquid handling system (Beckman Coulter, Indianapolis, Indiana, USA). RNA integrity and concentration were assessed using the HT RNA reagent kit (Caliper Life Sciences, Hopkinton, Massachusetts, USA) using a LabChip GX (PerkinElmer, Waltham, Massachusetts, USA). RNA samples with a RQS score of $>8.0$ were considered of acceptable quality for downstream applications.

For protein analyses, serum was collected (SST tubes) and stored frozen until use.

\section{Quantitative real-time PCR}

PAXgene-derived RNA was reverse transcribed to cDNA with a High-Capacity cDNA Reverse Transcription Kit (Applied Biosystems). Custom primers and probe sequences for BAFF were designed using the NCBI Nucleotide website and Primer Express software, and ordered from Applied Biosystems Custom Oligo Synthesis Service (Foster City, California, USA). BAFF sequences are as follows: primers 5'-TCGATGTATTCAA AATATGCCTGAA- $3^{\prime}$ and $5^{\prime}$-GCAATGCCAGCTGAATAG CA- $3^{\prime}$, and probe 5' ${ }^{\prime}$-6FAM-CACTACCCAATAATTCMGBNFQ- ${ }^{\prime}$. Quantitative measurement of BAFF was performed using a standard curve created with a custom DNA oligonucleotide with sequence: $5^{\prime}$-TGACTTTGTT TCGATGTATTCAAAATATGCCTGAAACACTACCCAATAATTCGTGC TATTCAGCTGGCATTGCAAAACTGGAA-3' Quantitative real-time PCR reactions were performed in duplicate using TaqMan Universal PCR Master Mix (Applied Biosystems) using the QuantStudio 12K Flex 
system (Applied Biosystems). BAFF gene expression levels were normalised against the housekeeping gene GAPDH. GAPDH sequences: primers 5'-ACCACCAGCCCCAGC AA- $3^{\prime}$ and $5^{\prime}$-GGGACTCCCCAGCAGTGA- $3^{\prime}$, and probe 5'-6FAM-AGCACAAGAGGAAGAGA-3'. GAPDH oligo sequence: 5'-AGACCCCTGGACCACCAGCCCCAGCAAG AGCACAAGAGGAAGAGAGAGACCGTCACTGCTGGGG AGTCCCTGCCACACTC-3'. Statistical analysis and graphing were done with GraphPad Prism software.

\section{Protein analysis}

BAFF serum protein level was assessed with the Rules-Based Medicine platform (Myriad RBM, Austin, Texas, USA). Their antibody method demonstrates $<1 \%$ cross-reactivity with APRIL.

\section{Statistical analysis}

We categorised patients, a priori, into tertiles. The groups were then compared with respect to the proportion of patients with various disease manifestations before, at the same time, and in the subsequent year after BAFF assessment. $p$ Values adjusted for age, race and sex were calculated using logistic regression. To account for the correlation between repeated visits from the same person in the analysis of the subsequent year of activity, we used robust variance estimates from generalised estimating equations, as implemented in SAS V.9.2.

\section{RESULTS}

\section{Patients with SLE}

Two hundred and seventy-five patients with SLE were evaluated for same-day disease activity, activity over the next year, serological parameters and BAFF gene expression level. The patients were $92 \%$ female with a mean age of 46 years $( \pm 12)$. The average SELENA-SLEDAI was $2.1( \pm 2.5)$ with a range from 0 to 11 . Further demographic characteristics are shown in online supplementary table S1.

\section{BAFF gene expression and relationship to SLE disease activity}

The distribution of BAFF gene expression is shown in figure 1A. There is significant skew with most patients having lower values of BAFF gene expression.

Higher average levels of BAFF gene expression were more common in African-Americans than in Caucasians (see online supplementary table S2). Though represented by much smaller numbers in our cohort, both Asians and 'Other' ethnicity had higher BAFF expression than African-Americans or Caucasians. We also noted associations between higher BAFF level gene expression and younger age. We show in online supplementary table S2 that, as a whole, both Caucasians and African-Americans have associations between increasing levels of BAFF and increasing disease activity (as measured by SLEDAI). This is explored in more detail below.
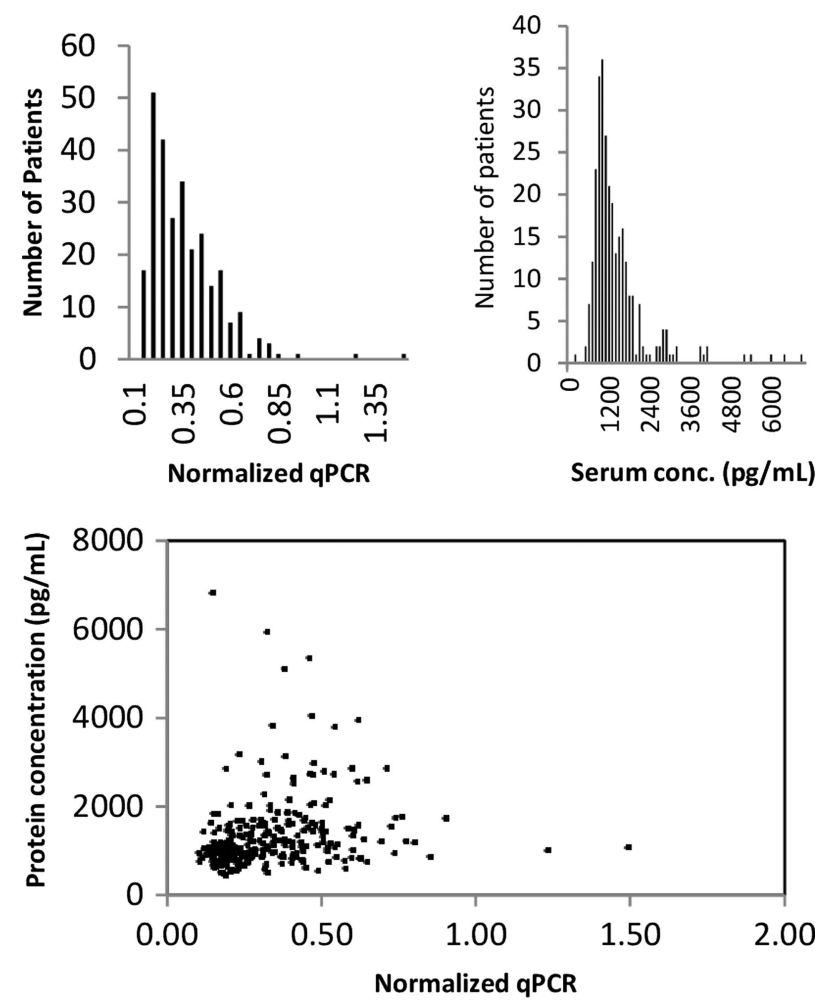

Figure 1 (A) Distribution of BAFF mRNA within the cohort. (B) Distribution of the BAFF protein levels within the cohort.

(C) Association between BAFF protein concentration and BAFF mRNA within patients in the cohort. BAFF, B cell activating factor.

Online supplementary table S3 shows the association between BAFF levels and history of various SLE-related manifestations. There was not a strong correlation between the individual components of the revised ACR classification criteria and BAFF gene expression level. The BAFF expression level was correlated with a prior history of leucopenia, more autoantibodies (anti-dsDNA, anti-Sm, anti-Ro, anti-La and anti-RNP) and low complement.

Table 1 shows the association between BAFF levels and SLE disease activity (clinical and serological) measured on the same day. Measures of disease activity were well correlated with BAFF gene expression level. Seventy-four per cent of patients with a high BAFF gene expression score had a SLEDAI $\geq 2$ compared with only $40 \%$ of those with a low BAFF gene expression score $(\mathrm{p}<0.0001)$. A PGA $>1$ (meaning moderate-to-high SLE activity) was found in $28 \%$ of the high BAFF gene expression group, but only $13 \%$ in the low BAFF gene expression group $(p=0.018)$. The association between measures of serological disease activity and BAFF gene expression was strong. Anti-dsDNA, hypocomplementaemia and elevation in ESR were all associated with higher BAFF expression. Those with high BAFF gene expression were more likely to have proteinuria $(20 \%)$ than those with low BAFF gene expression (6\%).

The distribution of BAFF serum protein in the cohort is shown in figure 1B. It is skewed to the right with a 
Table 1 BAFF gene expression and same-day SLE activity: percentage of patients in each of the BAFF categories (low, medium, high) that experience markers of disease activity on the day BAFF gene expression was measured

\begin{tabular}{|c|c|c|c|c|c|}
\hline Variable & $\begin{array}{l}\text { 1st Tertial } \\
(\%, n=91)\end{array}$ & $\begin{array}{l}\text { 2nd Tertial } \\
(\%, n=92)\end{array}$ & $\begin{array}{l}\text { 3rd Tertial } \\
(\%, n=92)\end{array}$ & p Value & $\begin{array}{l}\text { Adjusted } p \text { value, } \\
\text { age, ethnicity and sex }\end{array}$ \\
\hline$P G A>1$ & 13 & 15 & 28 & 0.018 & 0.25 \\
\hline SELENA-SLEDAI $\geq 2$ & 40 & 59 & 74 & $<0.0001$ & 0.0002 \\
\hline Urine protein:creatinine ratio $>0.5$ & 6 & 8 & 20 & 0.0041 & 0.23 \\
\hline Anti-dsDNA & 10 & 22 & 35 & 0.0003 & 0.0004 \\
\hline $\mathrm{C} 3<79 \mathrm{mg} / \mathrm{dL}$ & 7 & 6 & 22 & 0.0005 & 0.0012 \\
\hline $\mathrm{C} 4<12 \mathrm{mg} / \mathrm{dL}$ & 4 & 8 & 18 & 0.0085 & 0.0084 \\
\hline$E S R>20 \mathrm{~mm}$ & 38 & 50 & 65 & 0.0012 & 0.0092 \\
\hline
\end{tabular}

BAFF, B cell activating factor; PGA, physician global assessment; SLEDAI, Systemic Lupus Erythematosus Disease Activity Index; SELENA, Safety of Estrogens in Lupus Erythematosus: National Assessment.

small number of extremely high values. Most of the BAFF protein was clustered below serum levels of $2000 \mathrm{pg} / \mathrm{mL}$. We evaluated the association between BAFF gene transcript level and serum BAFF protein level in figure $1 \mathrm{C}$. There was a statistically significant, but somewhat small, correlation between transcript and protein levels $(\mathrm{r}=0.2)$.

\section{BAFF protein expression and relationship to SLE disease activity}

In a similar manner to the BAFF gene expression level, we looked for the association between the BAFF serum protein level and history of SLE disease activity (see online supplementary table S4). An association between history of malar rash, photosensitivity and arthritis and higher BAFF protein was seen that was not found with the mRNA. The association with history of anti-dsDNA and low complement and higher BAFF serum protein levels was observed similar to the BAFF gene expression levels.

Levels of BAFF serum protein did not associate with global SLE activity as measured by SELENA-SLEDAI or PGA measured on the same day though there was some borderline evidence of an association with SELENASLEDAI after adjusting $\mathrm{p}$ values for age, ethnicity and sex $(p=0.089) \quad$ (table 2$)$. This is likely due to the persistence of association with the same-day anti-dsDNA. Even looking at those patients with serum BAFF protein levels $>2000$ (37 patients), there was no association with disease activity (by PGA or SELENA-SLEDAI) by $\chi^{2}$ analysis (data not shown).

\section{Association with future SLE disease activity}

We further evaluated whether a one-time measurement of BAFF would be predictive of disease activity over the ensuing year (table 3). Clinic visits with high clinical disease activity were associated with high baseline BAFF gene expression levels, and when averaging measured clinical disease activity over the ensuing year, the association between disease activity and baseline BAFF gene expression remained strong. Clinical disease activity measured by two indices (PGA, SELENA-SLEDAI) was strongly associated with BAFF mRNA. We did not find a similarly predictive association of BAFF protein level and the next year's clinical activity (table 4) though higher levels of BAFF protein did predict persistence of elevated anti-dsDNA titres and hypocomplementaemia.

\section{DISCUSSION}

BAFF plays a central role in the pathogenesis of SLE. Previous studies in humans suggested that serum levels of the BLyS/BAFF protein correlated with disease

Table 2 BAFF serum protein and same-day SLE activity: percentage of patients in each of the BAFF categories (low, medium, high) that experience markers of disease activity at their clinical visit

\begin{tabular}{|c|c|c|c|c|c|}
\hline Variable & $\begin{array}{l}\text { Low } \\
(<950 \mathrm{pg} / \mathrm{mL}) \\
(\%, \mathrm{n}=96)\end{array}$ & $\begin{array}{l}\text { Medium } \\
(950-1400 \mathrm{pg} / \mathrm{mL}) \\
(\%, n=98)\end{array}$ & $\begin{array}{l}\text { High } \\
(>1400 \mathrm{pg} / \mathrm{mL}) \\
(\%, n=98)\end{array}$ & p Value & $\begin{array}{l}\text { Adjusted } p \text { value } \\
\text { for age, ethnicity } \\
\text { and sex }\end{array}$ \\
\hline$P G A>1$ & 20 & 15 & 21 & 0.53 & 0.47 \\
\hline SELENA-SLEDAI $\geq 2$ & 52 & 56 & 64 & 0.21 & 0.089 \\
\hline Urine protein:creatinine ratio $>0.5$ & 12 & 8 & 13 & 0.59 & 0.32 \\
\hline Anti-dsDNA $\geq 10$ (Crithidia) & 18 & 18 & 32 & 0.026 & 0.013 \\
\hline C3 $<79 \mathrm{mg} / \mathrm{dL}$ & 8 & 11 & 14 & 0.42 & 0.44 \\
\hline $\mathrm{C} 4<12 \mathrm{mg} / \mathrm{dL}$ & 8 & 9 & 12 & 0.63 & 0.77 \\
\hline $\mathrm{ESR}>20 \mathrm{~mm}$ & 45 & 51 & 58 & 0.19 & 0.11 \\
\hline
\end{tabular}

BAFF, B cell activating factor; PGA, physician global assessment; SLEDAI, Systemic Lupus Erythematosus Disease Activity Index; SELENA, Safety of Estrogens in Lupus Erythematosus: National Assessment. 
Table 3 BAFF gene expression and future activity: percentage of visits with future disease activity over the next year by BAFF gene expression

\begin{tabular}{|c|c|c|c|c|c|}
\hline Variable & $\begin{array}{l}\text { 1st Tertial } \\
(\%, n=91)\end{array}$ & $\begin{array}{l}\text { 2nd Tertial } \\
(\%, n=92)\end{array}$ & $\begin{array}{l}\text { 3rd Tertial } \\
(\%, n=92)\end{array}$ & p Value & $\begin{array}{l}\text { Adjusted } p \text { value for } \\
\text { age, ethnicity and sex }\end{array}$ \\
\hline$P G A>1$ & 12 & 12 & 29 & 0.0033 & 0.039 \\
\hline SELENA-SLEDAI $\geq 2$ & 35 & 52 & 70 & $<0.0001$ & $<0.0001$ \\
\hline Urine protein:creatinine ratio $\geq 0.5$ & 4 & 6 & 18 & 0.0034 & 0.049 \\
\hline Anti-dsDNA $\geq 10$ (Crithidia) & 9 & 16 & 35 & $<0.0001$ & 0.0005 \\
\hline C3 $<79$ & 6 & 7 & 22 & 0.0011 & 0.0056 \\
\hline C4 $<79$ & 4 & 8 & 18 & 0.0035 & 0.0033 \\
\hline $\mathrm{ESR}>20$ & 37 & 47 & 68 & $<0.0001$ & 0.0003 \\
\hline
\end{tabular}

activity, with increasing levels correlating with flare and decreasing levels correlating with reduced disease activity. ${ }^{28}$ However, these associations were relatively weak, and another study, ${ }^{35}$ suggested that measures of mRNA levels correlated more closely with disease activity than with changes in BAFF protein levels. Eilertsen $e t a t^{22}$ found no correlation between serum BAFF level and gene expression in peripheral blood mononuclear cells. We show here that, while BAFF protein concentration does associate with serological activity, we did not find a strong association between the BAFF protein concentration and global disease activity. Our study extends the work of Collins $e t a l,{ }^{35}$ to a larger, more heterogeneous population.

We show here that higher levels of BAFF gene expression are associated with higher measures of disease activity both by PGA and SELENA-SLEDAI though more strongly with SELENA-SLEDAI. In our study, BAFF gene expression has some utility as a serological marker of same-day global clinical disease activity and as a predictor of future activity. Also, the serological associations with BAFF gene expression are strong. Higher BAFF gene levels are significantly correlated with anti-dsDNA antibodies and hypocomplementaemia. While individually these markers are not greatly associated with SLE clinical disease activity, ${ }^{3}$ they remain useful as components of global activity. The recent subgroup analysis of the belimumab data showed that the subgroup with positive anti-dsDNA and low complement was most likely to respond to therapy. ${ }^{43}$ While hypocomplementaemia and anti-dsDNA antibodies are not sufficient clinical data to initiate belimumab or other B-cell-directed therapies, they do describe a group that may have higher BAFF gene expression levels and possibly a greater response to this form of therapy.

In the context of the complex history of BAFF, it is useful to consider possibilities of why the associations are not stronger than what we find here. First, though, in this study, we have looked at BAFF in all patients, it is highly likely that there are some patients in whom BAFF is likely to play a more pathological role. These may be patients with higher circulating levels of BAFF though this is far from certain. Recent elegant work examining BAFF's role in antibody affinity maturation within the germinal centre showed the very local and cell-specific effects of BAFF. ${ }^{44}$ Thus, it may be possible that high circulating levels are more a by-product of differential secretion and excretion than a measure of overall BAFF activity. Therefore, future work examining BAFF as a biomarker will need to examine how responsive BAFF is to changes in disease activity regardless of the level of

Table 4 BAFF serum protein and future activity: percentage of visits with future disease activity over the next year by BAFF protein level.

\begin{tabular}{|c|c|c|c|c|c|}
\hline Variable & $\begin{array}{l}\text { Low } \\
\text { (<950 pg/mL) } \\
\mathrm{N} \text { patients }=94 \\
\mathrm{~N} \text { visits }=309\end{array}$ & $\begin{array}{l}\text { Medium } \\
(950-1400 \mathrm{pg} / \mathrm{mL}) \\
\mathrm{N} \text { patients }=96 \\
\mathrm{~N} \text { visits }=306\end{array}$ & $\begin{array}{l}\text { High } \\
(>1400 \mathrm{pg} / \mathrm{mL}) \\
\mathrm{N} \text { patients }=96 \\
\mathrm{~N} \text { visits }=303\end{array}$ & p Value & $\begin{array}{l}\text { Adjusted } p \text { value } \\
\text { for age, ethnicity } \\
\text { and sex }\end{array}$ \\
\hline$P G A>1$ & 15 & 16 & 21 & 0.44 & 0.42 \\
\hline SELENA-SLEDAI $\geq 2$ & 51 & 50 & 58 & 0.37 & 0.079 \\
\hline Urine protein:creatinine ratio $\geq 0.5$ & 8 & 7 & 12 & 0.41 & 0.049 \\
\hline Anti-dsDNA $\geq 10$ (Crithidia) & 18 & 12 & 31 & 0.0034 & 0.0022 \\
\hline C3 $<79$ & 7 & 9 & 19 & 0.035 & 0.059 \\
\hline C4 $<79$ & 10 & 5 & 17 & 0.016 & 0.026 \\
\hline ESR $>20$ & 45 & 53 & 54 & 0.37 & 0.30 \\
\hline
\end{tabular}

BAFF, B cell activating factor; PGA, physician global assessment; SLEDAI, Systemic Lupus Erythematosus Disease Activity Index; SELENA, Safety of Estrogens in Lupus Erythematosus: National Assessment. 
expression. Second, BAFF has effects on more than one receptor (B-cell maturation antigen (BCMA), transmembrane activator and CAML interactor (TACI), B-cell activating factor receptor (BR3)). As is pointed out in Stohl's recent editorial, ${ }^{14}$ inhibiting BAFF may lead to worsening autoimmunity due to BAFF's effect on the TACI receptor on $\mathrm{T}_{\mathrm{FH}}$ cells.

We acknowledge multiple limitations of this study. This is a single-centre evaluation though large and heterogeneous. Further exploration of BAFF as a biomarker of lupus disease activity will require validation both over time as well as in other cohorts. We also note the relatively low disease activity in the cohort. Most patients have only mild disease activity (SELENA-SLEDAI of 2.1). With our lumping together of all patients with SELENA-SLEDAI higher than 2 as higher disease activity, there is some heterogeneity in this category; however, we were able to see a relatively continuous relationship between higher BAFF transcript levels and increasing levels of SELENA-SLEDAI (data not shown). Biologically, we have only measured BAFF and not the closely related APRIL. We did not seek to evaluate the multiple effector receptors or downstream effects of BAFF.

We and others have endeavoured to discover markers that would associate with disease activity and point to future disease activity as well. While these results await confirmation, we have shown that a measurement of whole blood gene expression of BAFF has greater utility in associating with SLE clinical disease activity than measurement of the gene product (the BAFF protein). We confirmed that BAFF gene expression is associated with serological activity, as was previously noted in the BAFF protein studies. Further, BAFF mRNA has utility in predicting which patients with SLE are more likely to have increased disease activity over the ensuing year. This is in excess of the information provided by standard measures of serological activity (low complement and anti-dsDNA). In a heterogeneous disorder such as SLE, across a heterogeneous population, there is likely to be a great complexity of cytokine interactions. It is, thus, encouraging that one cytokine can be evaluated to predict global activity.

Contributors EZ: interpretation of data, drafting and revision of manuscript. JB: study design, analysis and interpretation of data. JC: acquisition and analysis of data. NA: acquisition and analysis of data. AMR: study design, interpretation of data, critical review of manuscript. LM: study design, analysis and interpretation of data, critical review of manuscript. MP: conception and study design, interpretation of data, drafting and revision of the manuscript.

Funding The Hopkins Lupus Cohort is supported by NIH AR43727, EZ: research reported in this publication was supported by the National Institute of Arthritis and Musculoskeletal and Skin Diseases of the National Institutes of Health under Award Number T32AR048522.

Competing interests None declared.

Ethics approval Johns Hopkins IRB.

Provenance and peer review Not commissioned; externally peer reviewed.

Data sharing statement No additional data are available.
Open Access This is an Open Access article distributed in accordance with the Creative Commons Attribution Non Commercial (CC BY-NC 4.0) license, which permits others to distribute, remix, adapt, build upon this work noncommercially, and license their derivative works on different terms, provided the original work is properly cited and the use is non-commercial. See: http:// creativecommons.org/licenses/by-nc/4.0/

\section{REFERENCES}

1. Wahren-Herlenius M, Dörner T. Immunopathogenic mechanisms of systemic autoimmune disease. Lancet 2013;382:819-31.

2. Barr SG, Zonana-Nacach A, Magder LS, et al. Patterns of disease activity in systemic lupus erythematosus. Arthritis Rheum 1999;42:2682-8.

3. Ho A, Magder LS, Barr SG, et al. Decreases in anti-double-stranded DNA levels are associated with concurrent flares in patients with systemic lupus erythematosus. Arthritis Rheum 2001;44:2342-9.

4. Ho A, Barr SG, Magder LS, et al. A decrease in complement is associated with increased renal and hematologic activity in patients with systemic lupus erythematosus. Arthritis Rheum 2001;44:2350-7.

5. Esdaile JM, Abrahamowicz M, Joseph L, et al. Laboratory tests as predictors of disease exacerbations in systemic lupus erythematosus. Why some tests fail. Arthritis Rheum 1996;39:370-8.

6. Bauer JW, Petri M, Batliwalla FM, et al. Interferon-regulated chemokines as biomarkers of systemic lupus erythematosus disease activity: a validation study. Arthritis Rheum 2009;60:3098-107.

7. Kao AH, Navratil JS, Ruffing MJ, et al. Erythrocyte C3d and C4d for monitoring disease activity in systemic lupus erythematosus. Arthritis Rheum 2010;62:837-44.

8. Yap DYH, Lai KN. Cytokines and their roles in the pathogenesis of systemic lupus erythematosus: from basics to recent advances. J Biomed Biotechnol 2010;2010:1-10.

9. Jacob N, Stohl W. Cytokine disturbances in systemic lupus erythematosus. Arthritis Res Ther 2011;13:228.

10. Kirou KA, Lee C, George S, et al. Activation of the interferon-alpha pathway identifies a subgroup of systemic lupus erythematosus patients with distinct serologic features and active disease. Arthritis Rheum 2005;52:1491-503.

11. Landolt-Marticorena C, Bonventi G, Lubovich A, et al. Lack of association between the interferon-alpha signature and longitudinal changes in disease activity in systemic lupus erythematosus. Ann Rheum Dis 2009;68:1440-6.

12. Petri M, Singh S, Tesfasyone $\mathrm{H}$, et al. Longitudinal expression of type I interferon responsive genes in systemic lupus erythematosus. Lupus 2009;18:980-9.

13. Aringer M, Smolen JS. Therapeutic blockade of TNF in patients with SLE-promising or crazy? Autoimmun Rev 2012;11:321-5.

14. Stohl W. Editorial: the BAFFling immunology of systemic lupus erythematosus: Beyond B cells. Arthritis Rheumatol 2015;67:612-15.

15. Nardelli B, Belvedere O, Roschke V, et al. Synthesis and release of B-lymphocyte stimulator from myeloid cells. Blood 2001;97:198-204.

16. Litinskiy MB, Nardelli B, Hilbert DM, et al. DCs induce CD40independent immunoglobulin class switching through BLyS and APRIL. Nat Immunol 2002;3:822-9.

17. Lavie F, Miceli-Richard C, Quillard J, et al. Expression of BAFF (BLyS) in T cells infiltrating labial salivary glands from patients with Sjögren's syndrome. J Pathol 2004;202:496-502.

18. Moore PA, Belvedere O, Orr A, et al. BLyS: member of the tumor necrosis factor family and B lymphocyte stimulator. Science 1999;285:260-3.

19. Mackay F, Woodcock SA, Lawton $\mathrm{P}$, et al. Mice transgenic for BAFF develop lymphocytic disorders along with autoimmune manifestations. J Exp Med 1999;190:1697-710.

20. Huard B, Schneider P, Mauri D, et al. T Cell Costimulation by the TNF Ligand BAFF. J Immunol 2001;167:6225-31.

21. $\mathrm{Ng} \mathrm{LG}$, Sutherland APR, Newton R, et al. B cell-activating factor belonging to the TNF family (BAFF)-R is the principal BAFF receptor facilitating BAFF costimulation of circulating $T$ and $B$ cells. $J$ Immunol 2004;173:807-17.

22. Sutherland APR, $\mathrm{Ng} \mathrm{LG}$, Fletcher CA, et al. BAFF augments certain Th1-associated inflammatory responses. J Immunol 2005; 174:5537-44.

23. Khare SD, Sarosi I, Xia XZ, et al. Severe B cell hyperplasia and autoimmune disease in TALL-1 transgenic mice. Proc Natl Acad Sci USA 2000;97:3370-5.

24. Stohl W, Jacob N, Guo S, et al. Constitutive overexpression of BAFF in autoimmune-resistant mice drives only some aspects of systemic lupus erythematosus-like autoimmunity. Arthritis Rheum 2010;62:2432-42. 
25. Cheema GS, Roschke V, Hilbert DM, et al. Elevated serum B lymphocyte stimulator levels in patients with systemic immune-based rheumatic diseases. Arthritis Rheum 2001;44:1313-19.

26. Zhang J, Roschke V, Baker KP, et al. Cutting edge: a role for B lymphocyte stimulator in systemic lupus erythematosus. J Immunol 2001;166:6-10.

27. Stohl W, Metyas S, Tan S-M, et al. B lymphocyte stimulator overexpression in patients with systemic lupus erythematosus: longitudinal observations. Arthritis Rheum 2003;48:3475-86.

28. Petri M, Stohl W, Chatham W, et al. Association of plasma B lymphocyte stimulator levels and disease activity in systemic lupus erythematosus. Arthritis Rheum 2008;58:2453-9.

29. Becker-Merok A, Nikolaisen C, Nossent HC. B-lymphocyte activating factor in systemic lupus erythematosus and rheumatoid arthritis in relation to autoantibody levels, disease measures and time. Lupus 2006;15:570-6.

30. Hong SD, Reiff A, Yang H-T, et al. B lymphocyte stimulator expression in pediatric systemic lupus erythematosus and juvenile idiopathic arthritis patients. Arthritis Rheum 2009;60:3400-9.

31. Manzi S, Sánchez-Guerrero J, Merrill JT, et al. Effects of belimumab, a B lymphocyte stimulator-specific inhibitor, on disease activity across multiple organ domains in patients with systemic lupus erythematosus: combined results from two phase III trials. Ann Rheum Dis 2012;71:1833-8.

32. Ramanujam M, Wang $X$, Huang W, et al. Similarities and differences between selective and nonselective BAFF blockade in murine SLE. $J$ Clin Invest 2006;116:724-34.

33. Gross JA, Johnston J, Mudri S, et al. TACl and BCMA are receptors for a TNF homologue implicated in B-cell autoimmune disease. Nature 2000;404:995-9.

34. Navarra SV, Guzmán RM, Gallacher AE, et al. Efficacy and safety of belimumab in patients with active systemic lupus erythematosus: a randomised, placebo-controlled, phase 3 trial. Lancet 2011;377:721-31.
35. Collins CE, Gavin AL, Migone T-S, et al. B lymphocyte stimulator (BLyS) isoforms in systemic lupus erythematosus: disease activity correlates better with blood leukocyte BLyS mRNA levels than with plasma BLyS protein levels. Arthritis Res Ther 2006;8:R6.

36. La DT, Collins CE, Yang H-T, et al. B lymphocyte stimulator expression in patients with rheumatoid arthritis treated with tumour necrosis factor alpha antagonists: differential effects between good and poor clinical responders. Ann Rheum Dis 2008;67:1132-8.

37. Tan EM, Cohen AS, Fries JF, et al. The 1982 revised criteria for the classification of systemic lupus erythematosus. Arthritis Rheum 1982;25:1271-7.

38. Hochberg MC. Updating the American College of Rheumatology revised criteria for the classification of systemic lupus erythematosus. Arthritis Rheum 1997;40:1725.

39. Bombardier C, Gladman DD, Urowitz MB, et al. Derivation of the SLEDAI. A disease activity index for lupus patients. The Committee on Prognosis Studies in SLE. Arthritis Rheum 1992;35:630-40.

40. Petri M, Kim MY, Kalunian KC, et al. Combined oral contraceptives in women with systemic lupus erythematosus. $N$ Engl J Med 2005;353:2550-8.

41. Petri M, Hellmann D, Hochberg M. Validity and reliability of lupus activity measures in the routine clinic setting. $J$ Rheumatol 1992;19:53-9.

42. Eilertsen GØ, Van Ghelue M, Strand $\mathrm{H}$, et al. Increased levels of BAFF in patients with systemic lupus erythematosus are associated with acute-phase reactants, independent of BAFF genetics: a case-control study. Rheumatology (Oxford) 2011;50:2197-205.

43. Van Vollenhoven RF, Petri MA, Cervera R, et al. Belimumab in the treatment of systemic lupus erythematosus: high disease activity predictors of response. Ann Rheum Dis 2012;71:1343-9.

44. Goenka R, Matthews AH, Zhang B, et al. Local BLyS production by $T$ follicular cells mediates retention of high affinity $B$ cells during affinity maturation. J Exp Med 2014;211:45-56. 